\title{
Effect of fertilization and irrigation with magnetic water on the productivity of marjoram plant
}

\author{
By \\ Rania M. Khater \\ Department of Medicinal and Aromatic Plants, Desert Research Center, \\ Matarryia, Cairo, Egypt \\ Doi: 10.21608/asajs.2020.67987

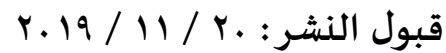

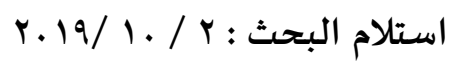

\section{Abstract:}

This research was conducted at the National Research Center greenhouse ring two consecutive seasons of 2013/2014 and 2014/2015, in order to study the effect of irrigation water types (tap water, magnetized water) and levels of ammonium sulfate $(0,7$, and $14 \mathrm{~g} / \mathrm{pot})$ and their interaction, on the vegetative growth and oil production of marjoram (Majorana hortensis L.) plant. The results showed that marjoram plants responded significantly to the different types of irrigation, as well as nitrogen fertilization and their interaction. Irrigation by magnetized water showed that a significant increase in vegetative growth; i.e. plant height, number of branches, fresh and dry weights of herb, stem, leaves and roots per plant and root length. Using nitrogen fertilizer rates gave significant increases in vegetative growth parameters, where the best treatment one was $14 \mathrm{~g} /$ pot. As for the interaction between types of irrigation water and nitrogen fertilizer rates, data showed that plants irrigated with magnetized water with addition of ammonium sulfate at a rate of $14 \mathrm{~g} / \mathrm{pot}$ recorded the highest values of the attributes of vegetative growth, production of oil, major compounds of oil and chemical components of marjoram plant. Magnetic water treatment with the addition of $14 \mathrm{~g} /$ pot 
ammonium sulfate recorded $43.38 \%$ of the terpineol-4-ol (the main compound of the oil), while irrigation with tap water recorded $26.41 \%$. Also this treatment increased some compounds of marjoram oil percent; such as $\alpha$-myrcene, $\alpha$ terpinene, $\alpha$-phellandrene, Ç-terpinene, $\alpha$-terpinolene, Llinalool, $\alpha$-terpineol and linalyl acetate with mean values of 1.08 , $5.91,1.13,12.45,2.40,3.48,3.53$ and 6.35 compared to tap water treatment, which gave $0.89,4.31,1.08,8.81,1.91,2.64$, 2.97 and 5.66 for these components; respectively. The obtained results also indicated the possibility of obtaining the highest values of chemical constituents such as total carbohydrates, nitrogen, phosphorus and potassium percentages when plants were irrigated with magnetized water with the addition of ammonium sulfate at a rate of $14 \mathrm{~g} /$ plant under the conditions of the experiment.

Key words: Majorana hortensis, magnetized water, ammonium sulfate

\section{Introduction:}

Marjoram (Majorana hortensis L.) is a bilateral strabismus herb belonging to the family Lamiaceae. It is native to the country's south-east of the Mediterranean basin. It is also grown in Germany, as an economic crop, which is used as a spice in many types of foods. Its leaves, flowers and oil are used as a medicine. It contains a volatile oil and many flavonoids; terpineol, glycosides, linalool, sabinene, triterpenes, thujanol and thymol, as effective materials (Edris et al., 2003 and El-Ghorab et al., 2004).

Marjoram from cleared vegetation is the best herbal antioxidant, emulsion flowers and dried branches are used to treat cough, asthma and infectious disorders and intestinal bloating, and are useful in the treatment of allergic nasal inflammation. Also, marjoram is used to treat the common cold

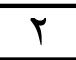


massage nasal ointment herb juice, rinsing the mouth, and using water extract of flowers is very useful for the body.

The most important medical benefits of the marjoram plant eliminates flatulence and stimulates the flow of bile and anti-inflammatory thoracic and tonsillitis. Also used for treatment of inflammation of the trachea, asthma and as a menstrual diuretic and good for stomach pains. Weed scientists also advised to use the marjoram herb for the treatment of glaucoma, because it contains anti-oxidants, as it prevents the occurrence of glaucoma (Tahraoui et al., 2007).

Marjoram is also used in the form of tea that regulates hormones and the menstrual cycle, and eliminates the hassles of menstruation. Since it is a general tonic and works to restore hormonal equilibrium, also removes excess water from the body (Triantaphyllou et al., 2001)

Medical studies confirm that marjoram has the effect of analgesic and anti-depressant, and the extract of the herb has a stimulating effect on the immune system, completely equal effect known to Nigella sativa. And marjoram oil is also used in the medical fields as one of the centrifugal gas vehicles in the installation of medicines that treat rheumatism, eczema and infectious ulcers (Farkas, 1981 and Leeja and Thoppil, 2007).

The use of the magnetic field as a treatment of water was observed for many industrial purposes. Agricultural and medical terms were used by Shimazaki Seed Company of the magnetic field in improvement of seed germination and acceleration of growth.

Many studies on using magnetized irrigation water were carried out (Nasher, 2008 and Hozayn and Abdul Qados, 2010), on paulownia seeds (Atak et al., 2000), vegetable crop (Çelik et al., 2008) and chick-pea (Maheshwari and Grewal, 2009). The magnetized irrigation water led to a significant increase in plant

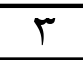


height and fresh and dry weight, where the increase was estimated at $20 \%$, compared with plants that were irrigated with nonmagnetic water. The various agricultural operations performed on marjoram plants have a significant impact on the vegetative growth and essential oil production. Particularly, nitrogen fertilizer is considered an important factor for increasing the production of marjoram vegetative growth and yield of fresh and dry leaves and volatile oil. This results have been reported by Usha and Patra (2003), Dasha et al. (2006) and Alsafar and Al-Hassan (2009), on Ocimum basilicum (Singh and Ramesh, 2000), Chrysanthemum coronarium and thyme (Baranauskienne et al., 2003), sweet fennel plants (Al-Said, 2005), rosemary (El-Shakry, 2005), Anethum graveolens (Min et al., 2005) and mint (Omer et al., 2008 and Phuong et al., 2008). The purpose of this research was to study the response of marjoram plants (Majorana hortensis, L. family Lamiaceae) to irrigation water (tap and magnetized water), and different levels of $\mathrm{N}$-fertilizer as well as their interaction on the productivity, essential oil and chemical composition.

\section{MATERIALS AND METHODS}

This work was carried out at the National Research Center greenhouse during two successive seasons of 2013- 2014 and $2014-2015$, to study the response of marjoram plants (Majorana hortensis, L. family Lamiaceae) to irrigation water types (tap water and magnetized water), different levels of $\mathrm{N}$ fertilizer as well as their interaction on vegetative growth, essential oil production and chemical compositions of plants. Seeds of majorana plants were gratefully obtained from the Department of Medicinal and Aromatic Plants, Ministry of Agriculture, Dokki,Giza,Egypt. The seeds were sown in the nursery bed on $15^{\text {th }}$ of November, for both seasons. After 45 days, seedlings were transplanted in plastic pots; $30 \mathrm{~cm}$

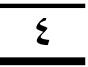


diameter, filled with sandy soil. The pots were watered according to the estimated irrigation requirements of majoram plants. The mechanical and chemical analyses of the soil are shown in table (1). The chemical analysis of irrigation water is tabulated in table (2). The magnetic water exposure used in the study is shown in fig. (1).

Table (1). The mechanical and chemical analysis of the soil pots experiment.

\begin{tabular}{lccccccc}
\hline $\begin{array}{l}\text { Mechanical } \\
\text { analysis }\end{array}$ & Value & $\begin{array}{c}\text { Soluble anions } \\
(\mathbf{m e q} / \mathbf{L})\end{array}$ & Value & $\begin{array}{c}\text { Soluble cations } \\
(\mathbf{m e q} / \mathbf{L})\end{array}$ & Value & $\begin{array}{c}\text { Available } \\
(\mathbf{m g} / \mathbf{L})\end{array}$ & Value \\
\hline Fine sand \% & 80.20 & $\mathrm{HCO}_{3}$ & 4.84 & $\mathbf{C a}$ & 5.95 & $\mathbf{N}$ & 8.21 \\
Coarse sand \% & 15.63 & $\mathbf{C L}$ & 7.63 & $\mathbf{M g}$ & 5.75 & $\mathbf{P}$ & 3.23 \\
Slit \% & 10.72 & $\mathrm{SO}_{4}$ & 8.13 & $\mathbf{N a}$ & 7.65 & $\mathbf{K}$ & 9.67 \\
Clay \% & 2.45 & $\mathbf{p H}$ & 7.60 & $\mathbf{K}$ & 1.25 & $\mathbf{C a C O}_{3}$ & 0.73 \\
Soil texture & & Sandy & & E.C Mmhos/ cm & & 2.10 & \\
\hline
\end{tabular}

Table (2). Chemical analysis of the used irrigation water.

\begin{tabular}{ccccccccccc}
\hline \multirow{2}{*}{ Treatment } & \multirow{2}{*}{$\mathbf{E C ~ d S m} \mathbf{~ d S m}^{-1}$} & \multirow{2}{*}{$\mathbf{p H}$} & \multicolumn{4}{c}{ Cations } & \multicolumn{4}{c}{ Anions } \\
\cline { 4 - 10 } & & $\mathbf{C a}^{2+}$ & $\mathbf{M g}^{2+}$ & $\mathbf{N a}^{+}$ & $\mathbf{K}^{+}$ & $\mathbf{C O}_{3}$ & $\mathbf{H C O}$ & $\mathbf{C l}^{-}$ & $\mathbf{S O}_{4}$ \\
\hline Tap water & 0.375 & 7.90 & 0.85 & 0.77 & 1.30 & 0.25 & 0.0 & 1.06 & 1.75 & 0.90 \\
Magnetized water & 0.468 & 7.82 & 1.20 & 1.30 & 1.30 & 0.29 & 0.0 & 1.41 & 2.00 & 1.21 \\
\hline
\end{tabular}
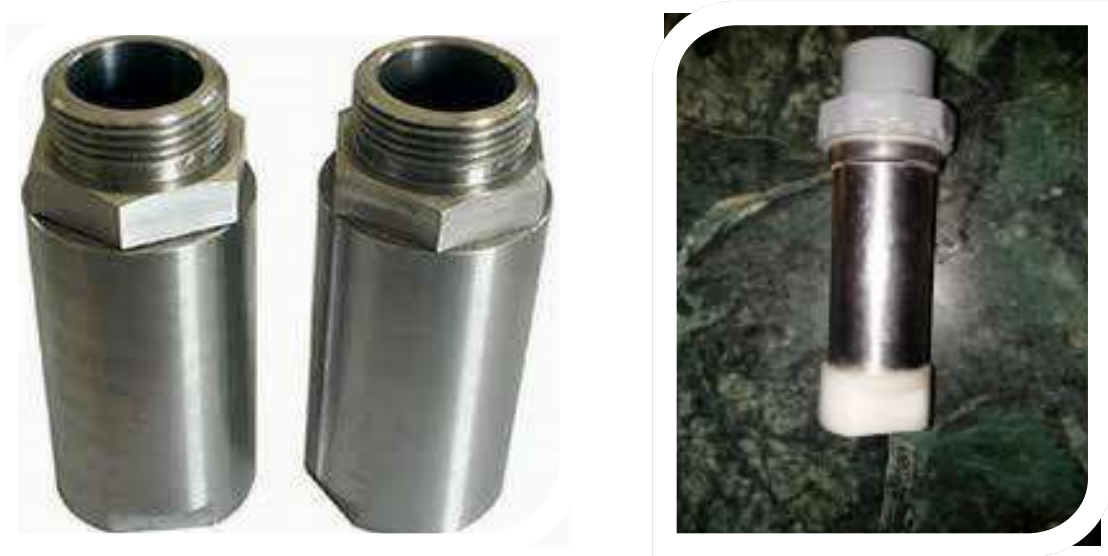
The experimental design was split plot design, with three replicates, types of irrigation water were the main plots and $\mathrm{N}$ fertilizer levels were sub plots. Each replicate contains 6 pots and one plant per pot.

The experiment included two factors. The first factor was type of irrigation water (tap water and magnetized water). The irrigation water was treated with a magnetized device before applying to plants. The water passed through 250 MT magnetron unit of $3.5 \mathrm{~cm}$ diameter, produced by magnetized technologies (Germany). While the second factor was $\mathrm{N}$-fertilizer with three levels $(0,7$,and $14 \mathrm{~g} / \mathrm{pot})$ as ammonium sulfate $(20.5 \% \mathrm{~N})$. The treatments were as follows:

1. Tap water

2. Magnetized water

3. Tap water $+7 \mathrm{~g} /$ pot ammonium sulfate

4. Tap water $+14 \mathrm{~g} /$ pot ammonium sulfate

5. Magnetized water $+7 \mathrm{~g} /$ pot ammonium sulfate

6. Magnetized water $+14 \mathrm{~g} / \mathrm{pot}$ ammonium sulfate

The nitrogen fertilizer was divided into two equal doses; the first addition was applied after one month from transplanting on $15^{\text {th }}$ of March, and the second one was added on $15^{\text {th }}$ of July (after two weeks of the first cut).

The following data were recorded after each cut (i) vegetative growth parameters [plant height $(\mathrm{cm})$, number of branches, fresh and dry weights of herb, stem, leaves, roots per plant (g) and root length $(\mathrm{cm})$ ] (ii) essential oil production including essential oil percentage of dry herb, determined after two cuts according to British Pharmacopoeia (1936), essential oil yield (ml/plant), the yield of oil produced per plant was calculated by multiplying the average dry weight of herb per plant by the oil percentage, and essential oil composition in the second cut of the second season, which was analyzed by using GC- mass according to Bunzen et al. (1969) and Hoftman (1967) 
methods and (iii) chemical constituents included total carbohydrate percentage determined according to method described by Herbert et al. (1971). Microelements (nitrogen, phosphorus and potassium) percentage were estimated. Nitrogen percentage was determined using Nissler method according to the procedure described by Koch and Mc-Meekin (1924); phosphorus percentage was determined according to the method of Troug and Mayer (1939) and potassium determination was done using photo-metrically flame photometer according to the method described by Brown and Lilleland (1946). The plants were harvested two times through the growing season. The first and the second cuts took place on $15^{\text {th }}$ of June and $15^{\text {th }}$ of September in both seasons, respectively.

The data recorded were statistically analyzed and treatments were compared by using least significant difference L.S.D. test at 5\% level according to Snedecor and Cochran (1980) by using Software (STATISTIX 9.0) (Analytical Software, 1985).

\section{RESULTS AND DISCUSSION}

\section{Plant Height and Number of Branches}

\subsection{Effect of irrigation water type}

Data presented in table (3) revealed that plant height and number of branches were affected by type of irrigation water. Irrigation with magnetized water treatment gave highly significant increase in plant height and number of branches compared to irrigation with un-magnetized water (tap water). This increase may be due to breaking down of hydrogen bonds of the molecule of magnetized water that led to smaller-sized water molecules, which affected the physical changes of water, viscosity and density. This facilitated the entry of the water through plant cellular membranes and increased the absorption of water and may affect the production of the hormone (IAA),

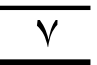


which leads to improve activity and division of plant cells. This reflects on the increase in plant height and number of branches (Rao, 2002). These results were reported in the two cuts in both seasons, and are in agreement with those found by Takac et al. (2002) on tomato and pepper, Nasher (2008) and Hozayn and Abdul Qados (2010) on chickpea.

\subsection{Effect of $\mathrm{N}$-fertilizer rates}

Data recorded in table (3) show that different rates of $\mathrm{N}$ fertilizer at all concentrations gave highly significant increase in plant height and number of branches in comparison to control in the two cuts and both seasons. Increasing $\mathrm{N}$-fertilizer rates increased plant height and number of branches. Furthermore, the superior treatment in this respect was that of $\mathrm{N}$-fertilizer of 14 $\mathrm{g} /$ pot, which gave highly significant increase in plant height and number of branches compared to the other ones under study in the two cuts in both seasons.

The increment in the plant height and number of branches as a result $\mathrm{N}$-fertilizer rates may be due to the effective role of the nitrogen, which is necessary for the synthesis of protein and cytokinin that affect the cell division and encourage the plant to carry more branches. These results are in accordance with those obtained by Baranauskienne et al. (2003) on thyme and Min et al. (2005) on Chrysanthemum coronarium.

\subsection{Effect of interaction}

Data presented in table (3) show that, the interaction treatments between type of irrigation water and $\mathrm{N}$-fertilizer rates caused highly significant increase in plant height and number of branches of marjoram comparing with control. The tallest plant and more branches in this regard were obtained by using magnetized water with $14 \mathrm{~g} / \mathrm{pot}$ comparing with other treatments. The reason for increasing in plant height and number of branches may be due to magnetized water that is easily absorbed by the process of root cells as water becomes a good

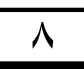


carrier of nutrients, which works to activate the role of nitrogen in the protein synthesis and cytokinin that affect the division and growth of cells and reflect on increase in plant height and number of branches. These results are in agreement with those obtained by Carbonell et al. (2000) on Oryza sativaL, Oldacay and Erdem (2002) on Helianthus annuus and Sharma et al. (2003) on psyllium.

Table (3). Effect of irrigation water type, $\mathrm{N}$-fertilizer rates and their interaction on plant height $(\mathrm{cm})$ and number of branches per plant of Majorana hortensis plant in 2013/2014 and 2014/2015 seasons.

\begin{tabular}{|c|c|c|c|c|c|c|c|c|}
\hline \multirow{5}{*}{ 总 } & \multicolumn{8}{|c|}{ N-fertilizer rates (B) } \\
\hline & Control & $14 \mathrm{~g} /$ pot & ${ }^{7} \mathrm{~g} /$ pot & $\begin{array}{c}\text { Means } \\
\text { (B) }\end{array}$ & Control & $14 \mathrm{~g} /$ pot & $7 \mathrm{~g} /$ pot & $\begin{array}{l}\text { Means } \\
\text { (B) }\end{array}$ \\
\hline & \multicolumn{8}{|c|}{ Plant height $(\mathrm{cm})$} \\
\hline & \multicolumn{8}{|c|}{ Season 1} \\
\hline & \multicolumn{4}{|c|}{ First cut } & \multicolumn{4}{|c|}{ Second cut } \\
\hline $\begin{array}{l}\text { Magnetized } \\
\text { water }\end{array}$ & 41.00 & 51.23 & 46.67 & 46.30 & 36.90 & 46.11 & 42.00 & 41.67 \\
\hline $\begin{array}{l}\text { Tap water } \\
\text { Means (A) }\end{array}$ & $\begin{array}{l}30.00 \\
35.50\end{array}$ & $\begin{array}{l}39.67 \\
45.45\end{array}$ & $\begin{array}{l}31.33 \\
39.00\end{array}$ & 33.67 & $\begin{array}{l}27.00 \\
31.95\end{array}$ & $\begin{array}{l}35.70 \\
40.91\end{array}$ & $\begin{array}{l}28.20 \\
35.10\end{array}$ & 30.30 \\
\hline \multirow[t]{3}{*}{ L.S.D. at $5 \%$} & A: 2.748 & B: 1.6 & & $\mathrm{AB}=3.220$ & A: 2.473 & B: 1 & 516 & $\mathrm{AB}=2.889$ \\
\hline & \multicolumn{8}{|c|}{ Season 2} \\
\hline & \multicolumn{4}{|c|}{ First cut } & \multicolumn{4}{|c|}{ Second cut } \\
\hline $\begin{array}{l}\text { Magnetized } \\
\text { water }\end{array}$ & 45.10 & 56.36 & 51.33 & 50.93 & 40.59 & 50.72 & 46.20 & 45.84 \\
\hline Tap water & 33.00 & 43.63 & 34.47 & 37.03 & 29.70 & 39.27 & 31.02 & 33.33 \\
\hline Means (A) & 39.05 & 49.99 & 42.90 & & 35.15 & 44.99 & 38.61 & \\
\hline \multirow[t]{4}{*}{ L.S.D. at $5 \%$} & A: 3.022 & B: 1.853 & & $\mathrm{AB}: 3.531$ & A: 2.722 & B:1. & 568 & $\mathrm{AB}: 3.179$ \\
\hline & \multicolumn{8}{|c|}{ Number of branches per plant } \\
\hline & \multicolumn{8}{|c|}{ Season 1} \\
\hline & \multicolumn{4}{|c|}{ First cut } & \multicolumn{4}{|c|}{ Second cut } \\
\hline $\begin{array}{l}\text { Magnetized } \\
\text { water }\end{array}$ & 12.00 & 18.33 & 15.00 & 15.11 & 15.60 & 23.83 & 19.50 & 19.64 \\
\hline Tap water & 6.33 & 10.67 & 8.67 & 8.56 & 8.23 & 13.86 & 11.26 & 11.12 \\
\hline Means (A) & 9.17 & 14.50 & 11.83 & & 11.92 & 18.85 & 15.38 & \\
\hline \multirow{3}{*}{ L.S.D. at $5 \%$} & \multicolumn{4}{|c|}{ B: $1.646 \quad A B: 1.947$} & A: 0.621 & \multicolumn{2}{|c|}{ B: 2.139} & $\mathrm{AB}: 2.531$ \\
\hline & \multicolumn{8}{|c|}{ Season 2} \\
\hline & \multicolumn{4}{|c|}{ First cut } & \multicolumn{4}{|c|}{ Second cut } \\
\hline $\begin{array}{l}\text { Magnetized } \\
\text { water }\end{array}$ & 16.80 & 25.67 & 21.00 & 21.16 & 20.16 & 30.80 & 25.20 & 25.38 \\
\hline Tap water & 8.87 & 14.93 & 12.13 & 11.98 & 10.64 & 17.92 & 14.56 & 14.37 \\
\hline Means (A) & 12.83 & 20.30 & 16.57 & & 15.40 & 24.36 & 19.88 & \\
\hline L.S.D. at $5 \%$ & $\mathrm{~A}: 0.669$ & B: 2.3 & & $\mathrm{AB}: 2.726$ & A: 0.803 & B: 2 & 764 & $\mathrm{AB}: 3.271$ \\
\hline
\end{tabular}

2. Fresh and Dry Weights of Herb, Stem, Leaves, Roots and Roots Length per Plant 2.1. Effect of irrigation water type 
The data given in tables $(4,5$ and 6$)$ and fig. (2) indicate that, fresh and dry weights of herb, leaves, stem, root and roots length per plant of marjoram showed highly significant increase with type of irrigation water. Moreover, using magnetized water increased these parameters. The best treatment in these connections was that of magnetized water, which recorded highly significant increase compared to tap water. These results hold in the same direction in the two cuts in both seasons.

This result may be due to that magnetized irrigation water increases plant growth by crash hydrogen bonds, which facilitates the absorption of water by the root cells, as water becomes a good carrier of nutrients. Hence, biological processes within the plant increases, such as an increase in photosynthesis and the plants process an increase in the production of plant hormones; such as cytokinin, IAA and $\mathrm{GA}_{3}$ and protein production increases (Colic et al., 1998). These results are in accordance with those obtained by, Martinez et al. (2000) on Hordeum vulgare, Belyavskaya (2001) on pea root and Marinkovic et al. (2002) on potato.

\subsection{Effect of $\mathbf{N}$-fertilizer rates}

Data presented in tables (4, 5 and 6) and fig. (2) demonstrate that, increasing $\mathrm{N}$-fertilizer rates treatments led to highly significant increase in fresh and dry weights of herb, leaves, stem, root and roots length per marjoram plant in comparison to control, in the two cuts in both seasons. Also, the highest increase in this respect was obtained by using $14 \mathrm{~g} / \mathrm{pot}$ compared to the control. Moreover, increasing $\mathrm{N}$-fertilizer rates increased these parameters. 
This increment in the fresh and dry weights of herb, leaves, stem, root and roots length per plant as a result of $\mathrm{N}$ fertilizer rates may be due to the effective role of nitrogen nutrition, which led to an increase in plant height and number of branches, which was reflected in producing more fresh and dry weights of herb, leaves, stem, root and roots length per marjoram plant. These results are in agreement with those obtained by
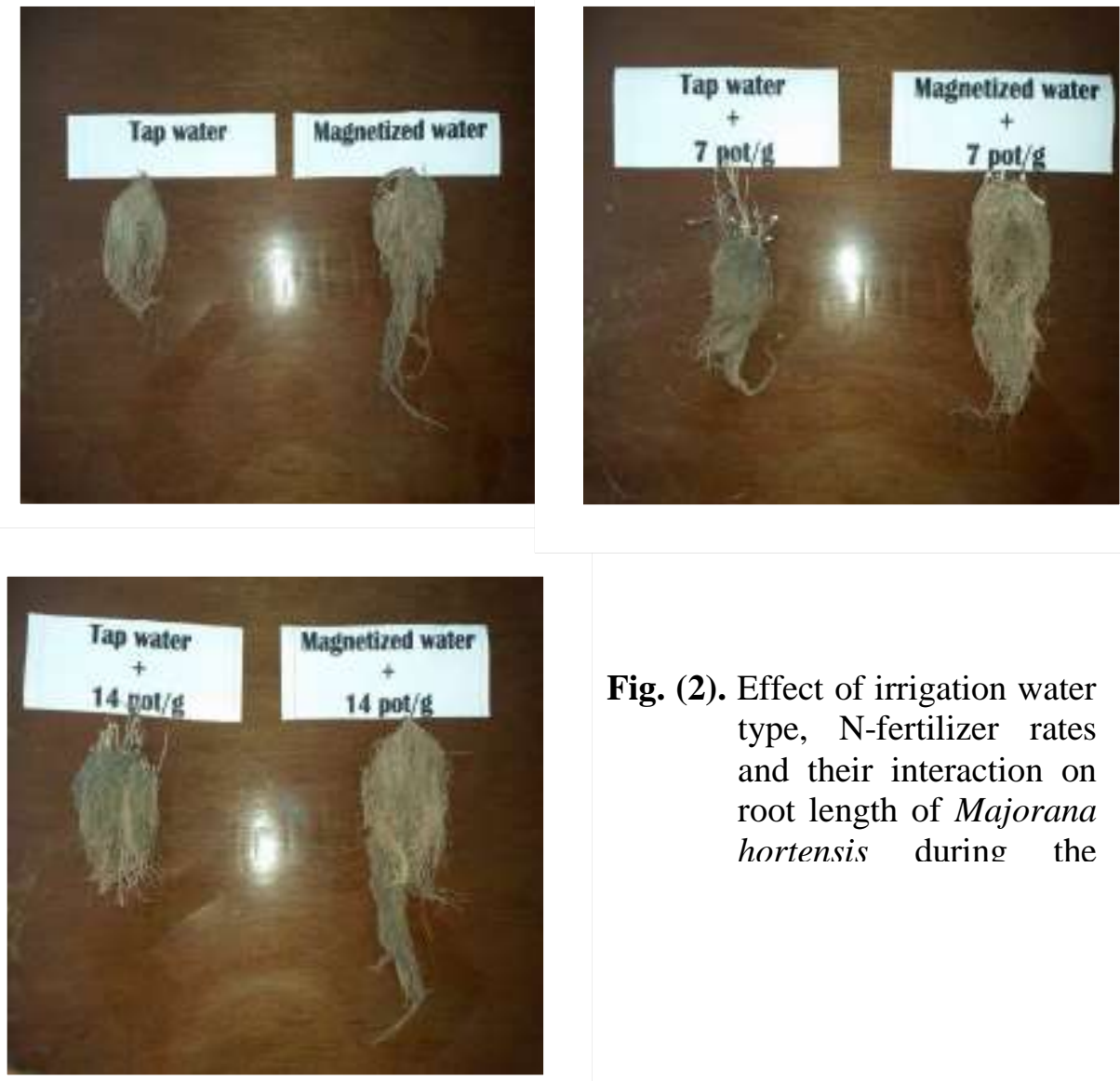

Fig. (2). Effect of irrigation water type, $\mathrm{N}$-fertilizer rates and their interaction on root length of Majorana hortensis during the 
Usha and Patra (2003) on Mentha arvensis var. piperascens and Al-Said (2005) on Anethum graveolens.

Table (4). Effect of irrigation water type, $\mathrm{N}$-fertilizer rates and their interaction on fresh weight of herb, stem and leaves per plant (g) of Majorana hortensis plant in 2013/2014 and 2014/2015 seasons.

\begin{tabular}{|c|c|c|c|c|c|c|c|c|}
\hline \multirow{5}{*}{ 恶 } & \multicolumn{8}{|c|}{ N-fertilizer (B) } \\
\hline & Control & 14 g/pot & $7 \mathrm{~g} /$ pot & Means (B) & Control & 14 g/pot & 7 gipot & Means (B) \\
\hline & \multicolumn{8}{|c|}{ Fresh weight of herb per plant $(\mathrm{g})$} \\
\hline & \multicolumn{8}{|c|}{ Season 1} \\
\hline & \multicolumn{4}{|c|}{ First cut } & \multicolumn{4}{|c|}{ Second cut } \\
\hline Magnetized water & 55.343 & 80.533 & 70.353 & 68.743 & 39.290 & 57.173 & 49.943 & 48.802 \\
\hline Tap water & 45.287 & 67.217 & 58.477 & 56.993 & 32.147 & 47.720 & 41.513 & 40.460 \\
\hline Means (A) & 50.315 & 73.875 & 64.415 & & 35.718 & 52.447 & 45.728 & \\
\hline \multirow[t]{3}{*}{ L.S.D. at $5 \%$} & A: 4.994 & B: & .029 & AB: 5.813 & A: 3.542 & B: 2.1 & & $\mathrm{AB}: 4.125$ \\
\hline & \multicolumn{8}{|c|}{ Season 2} \\
\hline & \multicolumn{4}{|c|}{ First cut } & \multicolumn{4}{|c|}{ Second cut } \\
\hline Magnetized water & 66.413 & 96.640 & 84.427 & 82.493 & 47.147 & 68.610 & 59.937 & 58.564 \\
\hline Tap water & 54.343 & 80.660 & 70.170 & 68.391 & 38.580 & 57.263 & 49.813 & 48.552 \\
\hline Means (A) & 60.378 & 88.650 & 77.298 & & 42.863 & 62.937 & 54.875 & \\
\hline \multirow[t]{4}{*}{ L.S.D. at $5 \%$} & A : 5.998 & & 635 & $\mathrm{AB}: 6.979$ & A: 4.259 & B: 2 . & 581 & $A B: 4.956$ \\
\hline & \multicolumn{8}{|c|}{ Fresh weight of stem per plant (g) } \\
\hline & \multicolumn{8}{|c|}{ Season 1} \\
\hline & \multicolumn{4}{|c|}{ First cut } & \multicolumn{4}{|c|}{ Second cut } \\
\hline Magnetized water & 19.173 & 27.897 & 24.373 & 23.814 & 11.887 & 17.297 & 15.107 & 14.763 \\
\hline Tap water & 15.687 & 23.283 & 20.253 & 19.741 & 9.723 & 14.437 & 12.560 & 12.240 \\
\hline Means (A) & 17.430 & 25.590 & 22.313 & & 10.805 & 15.867 & 13.833 & \\
\hline \multirow[t]{3}{*}{ L.S.D. at $5 \%$} & A: 1.727 & B: 1 & & $\mathrm{AB}: 2.011$ & A: 1.070 & B: 0.6 & & $\mathrm{AB}: 1.247$ \\
\hline & \multicolumn{8}{|c|}{ Season 2} \\
\hline & \multicolumn{4}{|c|}{ First cut } & \multicolumn{4}{|c|}{ Second cut } \\
\hline Magnetized water & 23.003 & 33.477 & 29.247 & 28.576 & 14.263 & 20.753 & 18.133 & 17.717 \\
\hline Tap water & 18.827 & 27.943 & 24.307 & 23.692 & 11.670 & 17.323 & 15.070 & 14.688 \\
\hline Means (A) & 20.915 & 30.710 & 26.777 & & 12.967 & 19.038 & 16.602 & \\
\hline \multirow[t]{4}{*}{ L.S.D. at $5 \%$} & A: 2.075 & & 260 & $\mathrm{AB}: 2.416$ & A: 1.282 & B: 0.7 & & $A B: 1.494$ \\
\hline & \multicolumn{8}{|c|}{ Fresh weight of leaves per plant (g) } \\
\hline & \multirow{2}{*}{\multicolumn{8}{|c|}{ Season 1}} \\
\hline & & \multicolumn{3}{|c|}{ First cut } & \multicolumn{4}{|c|}{ Second cut } \\
\hline Magnetized water & 36.173 & 52.633 & 45.983 & 44.930 & 27.403 & 39.877 & 34.837 & 34.039 \\
\hline Tapwater & 29.600 & 43.933 & 38.217 & 37.250 & 22.423 & 33.283 & 28.953 & 28.220 \\
\hline Means (A) & 32.887 & 48.283 & 42.100 & & 24.913 & 36.580 & 31.895 & \\
\hline L.S.D. at $5 \%$ & A: 3.264 & B: 1 & & $A B: 3.797$ & A: 2.472 & B: 1. & 999 & $\mathrm{AB}: 2.877$ \\
\hline & & & & Seas & n 2 & & & \\
\hline & & Firs & cut & & & Secon & $\mathrm{d}$ cut & \\
\hline Magnetized water & 43.407 & 63.163 & 55.180 & 53.917 & 32.883 & 47.853 & 41.807 & 40.848 \\
\hline Tap water & 35.517 & 52.723 & 45.863 & 44.701 & 26.910 & 39.940 & 34.743 & 33.864 \\
\hline Means (A) & 39.462 & 57.943 & 50.522 & & 29.897 & 43.897 & 38.275 & \\
\hline L.S.D. at 5\% & A: 3.914 & B: 2 & 375 & $\mathrm{AB}: 4.556$ & A: 2.968 & B: 1.8 & & $\mathrm{AB}: 3.455$ \\
\hline
\end{tabular}

Table (5). Effect of irrigation water type, $\mathrm{N}$-fertilizer rates and their interaction on dry weight of herb, stem and leaves per plant $(\mathrm{g})$ of Majorana hortensis plant in 2013/2014 and 2014/2015 seasons. 


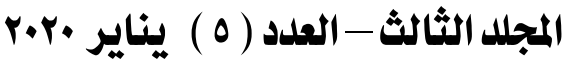

\section{المجلة العربية للعلوم الزراعية}

\begin{tabular}{|c|c|c|c|c|c|c|c|c|}
\hline \multirow{4}{*}{ 孪总 } & \multicolumn{8}{|c|}{ N-fertilizer (B) } \\
\hline & Control & $14 \mathrm{~g} /$ pot & $7 \mathrm{~g} /$ pot & Means (B) & Control & $14 \mathrm{~g} /$ pot & $7 \mathrm{~g} / \mathrm{pot}$ & Means (B) \\
\hline & \multicolumn{4}{|c|}{ Season 1} & \multicolumn{4}{|c|}{ Season 2} \\
\hline & \multicolumn{8}{|c|}{ Fresh weight of root per plant $(\mathrm{g})$} \\
\hline $\begin{array}{l}\text { Magnetized } \\
\text { water }\end{array}$ & 14.553 & 25.267 & 22.013 & 20.611 & 16.300 & 28.300 & 24.657 & 23.086 \\
\hline Tap water & 10.640 & 19.133 & 15.653 & 15.142 & 11.917 & 21.430 & 17.530 & 16.959 \\
\hline Means (A) & 12.597 & 22.200 & 18.833 & & 14.108 & 24.865 & 21.093 & \\
\hline \multirow[t]{2}{*}{ L.S.D. at 5\% } & \multicolumn{3}{|c|}{ B: 1.873} & $\mathrm{AB}: 3.444$ & A: 3.244 & \multicolumn{2}{|c|}{ B: 2.097} & $\mathrm{AB}: 3.859$ \\
\hline & \multicolumn{8}{|c|}{ Dry weight of root per plant (g) } \\
\hline $\begin{array}{l}\text { Magnetized } \\
\text { water }\end{array}$ & 5.530 & 9.600 & 8.363 & 7.831 & 6.193 & 10.753 & 9.370 & 8.772 \\
\hline Tap water & 4.043 & 7.266 & 5.950 & 5.753 & 4.527 & 8.143 & 6.660 & 6.443 \\
\hline Means (A) & 4.786 & 8.433 & 7.156 & & 5.360 & 9.448 & 8.015 & \\
\hline \multirow[t]{2}{*}{ L.S.D. at $5 \%$} & \multicolumn{3}{|c|}{ B: 0.711} & $\mathrm{AB}: 1.312$ & A: 1.234 & \multicolumn{2}{|c|}{ B: 0.799} & $\mathrm{AB}: 1.469$ \\
\hline & \multicolumn{8}{|c|}{ Length of roots $(\mathrm{cm})$} \\
\hline $\begin{array}{l}\text { Magnetized } \\
\text { water }\end{array}$ & 21.120 & 32.267 & 26.400 & 26.596 & 22.777 & 34.797 & 28.470 & 28.681 \\
\hline Tap water & 11.147 & 15.253 & 18.773 & 15.058 & 12.023 & 20.247 & 16.447 & 16.239 \\
\hline Means (A) & 16.133 & 25.520 & 20.827 & & 17.400 & 27.522 & 22.458 & \\
\hline L.S.D. at $5 \%$ & A: 1.658 & B: 4.0 & & $\mathrm{AB}: 4.544$ & A: 1.788 & B: 4.3 & & $\mathrm{AB}: 4.900$ \\
\hline
\end{tabular}

Table (6). Effect of irrigation water type, $\mathrm{N}$-fertilizer rates and their interaction on fresh and dry weights of roots per plant $(\mathrm{g})$ and length of roots $(\mathrm{cm})$ of Majorana hortensis plant in 2013/2014 and 2014/2015 seasons.

\begin{tabular}{|c|c|c|c|c|c|c|c|}
\hline \multirow{5}{*}{ 总 } & \multicolumn{7}{|c|}{ N-fertilizer (B) } \\
\hline & Conmol & 14 e/pot & 7 e poot & Means $(H)$ & Centrol & 14 ecipot & Means (B) \\
\hline & \multicolumn{7}{|c|}{ Dry weithe of berb per plant (e) } \\
\hline & \multicolumn{7}{|c|}{ Season 1} \\
\hline & \multicolumn{4}{|c|}{ First cut } & \multirow{2}{*}{\multicolumn{3}{|c|}{ Second cut }} \\
\hline Matratized water & 19.370 & 28.183 & 24.623 & 24.059 & 13.750 & & \\
\hline Tap water & I5. 853 & 23,523 & 20.463 & 19.947 & $11.25 \overline{3}$ & 16.703 & 14,162 \\
\hline Means (A) & 17.612 & 25.853 & 22.543 & & 12.502 & $18.357 \quad 16.005$ & \\
\hline \multirow{3}{*}{ I.S.D, at $5 \%$} & \multicolumn{3}{|c|}{ B: 1.060} & $A B: 2.036$ & A. $1: 240$ & B: 0.755 & $A B=1.445$ \\
\hline & \multicolumn{7}{|c|}{ Seanon 2} \\
\hline & & \multicolumn{3}{|c|}{ Second cat } \\
\hline Magnetized water & 23.243 & 93.827 & 29.350 & 28.873 & 16.303 & $24.013 \quad 20.979$ & 20.498 \\
\hline Tapwater & 19.020 & 28.233 & 24.560 & 23.938 & 13.503 & 17.437 & 16.994 \\
\hline Meano $(A)$ & 21.132 & 31.030 & 27.055 & & 15.003 & $22.028 \quad 19.207$ & \\
\hline \multirow[t]{4}{*}{ I..5.D, at $5 \%$} & A: 2.102 & B: 1 & 274 & $A B: 2.446$ & A: 1.494 & B: 0.904 & $A B: 1.737$ \\
\hline & \multicolumn{7}{|c|}{ Dry weight of stem par plant (E) } \\
\hline & \multirow{2}{*}{\multicolumn{7}{|c|}{ Season 1}} \\
\hline & & & & & & & \\
\hline Magrnutized water & 6,710 & 9,763 & 8.530 & 8.334 & 4,160 & 5,256 & 5.166 \\
\hline Tap watar & 5.490 & 8.153 & 7,086 & 6.910 & 3.406 & 4396 & 4285 \\
\hline Means $(A)$ & 6.100 & 8.958 & 7.505 & & 3.783 & $5.553 \quad 4.541$ & \\
\hline \multirow[t]{3}{*}{ L, S,D, $A$, 5\% } & A: 0.599 & B: 0 & 367 & AB: 0.700 & A: 0.384 & B: 0.226 & AB: 0.443 \\
\hline & \multirow{2}{*}{\multicolumn{7}{|c|}{ Seasan 2}} \\
\hline & & & & & & & \\
\hline Maprantized water & 8.053 & 11.713 & 10.237 & 10.001 & 4.9933 & $7.2633 \quad 6.3467$ & 6.2011 \\
\hline Tap water & 6.390 & 9.780 & 8.507 & 8.292 & 4.0833 & 6.0633 & 5,1400 \\
\hline Means (A) & 7.322 & 10.747 & 9.372 & & 4.5383 & $6.6633 \quad 5.8100$ & \\
\hline \multirow[t]{3}{*}{ L, $5, \mathrm{D}, \mathrm{at}, 5 \%$} & A: 0.731 & B: 0 & 440 & AB: 0.849 & A: 0.450 & B: 0.272 & AB: 0.523 \\
\hline & \multirow{2}{*}{\multicolumn{7}{|c|}{$\begin{array}{l}\text { Dony weight of leaves per plant (E) } \\
\text { Seanon } 1\end{array}$}} \\
\hline & & & & & & & \\
\hline Matteetixed water & 12.660 & \multicolumn{3}{|c|}{ Tirst eat } & \multicolumn{3}{|c|}{ Second cat } \\
\hline Tap water & 10.360 & is 5.380 & $\begin{array}{l}16.093 \\
13.377\end{array}$ & $\begin{array}{l}13.724 \\
13.039\end{array}$ & $\begin{array}{l}9.590 \\
7.847\end{array}$ & $\begin{array}{ll}13.957 & 12.197 \\
11.650 & 10.133\end{array}$ & $\begin{array}{l}11.914 \\
9.877\end{array}$ \\
\hline Means $(A)$ & i1.510 & 16.900 & 14.735 & & $8.71 \mathrm{~s}$ & $12.803 \quad 11.165$ & \\
\hline \multirow[t]{3}{*}{ L.S.D, at $8 \%$} & \multicolumn{3}{|l|}{ A 1.147} & $A B: 1.332$ & A: 0.862 & B: 0.525 & $A B: 1.005$ \\
\hline & \multicolumn{7}{|c|}{$\operatorname{Seanan} 2$} \\
\hline & \multirow{2}{*}{\multicolumn{4}{|c|}{22.107 firse cut }} & \multicolumn{2}{|r|}{ Second cut } & \\
\hline Mognetized water & & & & 18.870 & 16.503 & 24.013 & 20.498 \\
\hline Tapwiser & 12.430 & 18.453 & 16.053 & 15.646 & 13.503 & 20.043 & 16.994 \\
\hline Means (A) & 13.812 & 20.280 & 17.682 & & 15.003 & $22.028 \quad 19.207$ & \\
\hline I..S.D, at $5 \%$ & A 1.373 & B: 0 & 833 & AB: 1.598 & A. 1.494 & B: 0.904 & $A B: 1.737$ \\
\hline
\end{tabular}




\subsection{Effect of interaction}

From the data presented in tables $(4,5$ and 6$)$ and fig. (2), it is obvious that increasing $\mathrm{N}$-fertilizer rates under the two types of water irrigation increased the fresh and dry weights of herb, leaves, stem, root and roots length per plant. However, the superior result in this concern was obtained by using magnetized water treatment in all cases, which gave highly significant increase comparing with other interactions.

Moreover, the interaction treatments between type of irrigation water and $\mathrm{N}$-fertilizer rates gave highly significant increase in fresh and dry weights of herb, leaves, stem and root per marjoram plant comparing with that of other treatments.

The treatments of magnetized water with $7 / \mathrm{g}$ and tab water with $14 / \mathrm{g}$ of $\mathrm{N}$-fertilizer increased fresh and dry weights of herb, leaves, stem, root and roots length per plant, but this increase was insignificant compared with using tap water only. Also, the treatments of tap water with $7 / \mathrm{g}$ of $\mathrm{N}$-fertilizer and magnetized water increased fresh and dry weights of herb, leaves, stem, root and roots length per plant, but this increase was insignificant compared to using tap water only. These results were recorded in the two cuts in two seasons.

The increase of growth may be due to that magnetized water increases plant growth by facilitating the absorption of water by root cells, as water becomes a good carrier for foodstuffs. Thus it encourages the active role of the nitrogen, which leads to an increase in photosynthesis and production of plant hormones and increasing the production of the protein, which is reflected in the increase in growth. These results are in harmony with those obtained by Atak et al. (2000) on paulownia seeds, Maheshwari et al. (2000) on psyllium plants and Çelik et al. (2008) on Paulownia node.

\section{Essential Oil Production and Chemical Constituents 3.1. Effect of irrigation water type}


Data presented in table (7) reveal that, essential oil production including essential oil percentage and essential oil yield ( $\mathrm{ml} / \mathrm{plot})$ increased when irrigated with magnetized water. Moreover, treatments gave an increase in essential oil production; including essential oil percentage and essential oil yield (ml/plot) compared with irrigation with tap water (unmagnetized water). Furthermore, irrigation with magnetized water led an increase in essential oil production; including essential oil percentage and essential oil yield (ml/plot) compared to irrigated plant with tap water.

This increment in these parameters may be due to the magnetized water that increased the vegetative growth and was reflected in essential oil percentage. These results were in agreement with those obtained by Hilal et al. (2002) on citrus and Alsafar and Al-Hassan (2009) on Mentha longifolia plant.

\subsection{Effect of $\mathbf{N}$-fertilizer rates}

Data recorded in table (7) show that, $\mathrm{N}$-fertilizer rates increased essential oil production including essential oil percentage and essential oil yield (ml/plot) in comparison with control in the two cuts in both seasons. Moreover, increasing Nfertilizer rates increased essential oil production including essential oil percentage and essential oil yield (ml/plot). Furthermore, the superior treatment in this respect was that of $\mathrm{N}$ fertilizer rates $14 \mathrm{~g} /$ pot which gave higher increase in these parameters in the two cuts in both seasons. Generally, the essential oil percentage and essential oil yield ( $\mathrm{ml} / \mathrm{plot}$ ) were higher in the second cut than first cut.

The increment in the essential oil percentage and essential oil yield (ml/plot) as a result of $\mathrm{N}$-fertilizer rates could be attributed to the effective role of nitrogen in enhancing vegetative growth and essential oil percentage in plant. These results are in accordance with those obtained by Singh and 
Ramesh (2000) on rosemary and Omer et al. (2008) on Ocimum americanum.

\subsection{Effect of interaction}

The results presented in table (7) indicate that increasing $\mathrm{N}$-fertilizer rates under type of irrigation water increased essential oil production; including essential oil percentage and essential oil yield ( $\mathrm{ml} / \mathrm{plot})$ of marjoram plant. The interaction between all treatments gave increase in these parameters and this increase was significantly compared to each treatment and control (tap water). The highest values in this respect were obtained by using $14 \mathrm{~g} /$ pot of $\mathrm{N}$-fertilizer rates combined with using magnetized water, comparing with the other interactions. This treatment gave highly significant increase comparing with other interactions. These results hold true in the two cuts in both seasons.

The reason for increasing essential oil may be due to that magnetized water led to the revitalization of the active role of nitrogen and thus led to an increase in the plant growth, which led to an increase in essential oil percentage and yield ( $\mathrm{ml} / \mathrm{plot})$. These results are in accordance with those obtained by Alsafar and Al-Hassan (2009) on Mentha longifolia plant and Maheshwari and Grewal (2009) on vegetables crop.

On the other hand, data presented in table (8) illustrate that the essential oil of marjoram plants obtained from the dry herb in the second cut of the second season (2014/2015) was analyzed by using GC Mass. The percentage of the main components were calculated and presented in table (8) and fig. $(1,2,3,4,5$ and 6). Data show that terpinen-4-ol is the major compound in marjoram oil.

Table (7). Effect of irrigation water type, $\mathrm{N}$-fertilizer rates and their interaction on essential oil percentage and yield per plant (ml) of Majorana hortensis L plant in2013/2014 and 2014/2015 seasons. 


\begin{tabular}{|c|c|c|c|c|c|c|c|c|}
\hline \multirow{5}{*}{ Irrigation type } & \multicolumn{8}{|c|}{ N-fertilizer (B) } \\
\hline & Control & $14 \mathrm{~g} / \mathrm{pot}$ & $7 \mathrm{~g} / \mathrm{po}$ & Means (B) & Control & $14 \mathrm{~g} / \mathrm{pot}$ & $7 \mathrm{~g} / \mathrm{pot}$ & Means (B) \\
\hline & \multicolumn{8}{|c|}{ Essential oil percentage } \\
\hline & \multicolumn{8}{|c|}{ Season 1} \\
\hline & \multicolumn{4}{|c|}{ First cut } & \multicolumn{4}{|c|}{ Second cut } \\
\hline Magnetized water & 0.753 & 1.396 & 1.263 & 1.137 & 0.680 & 1.260 & 1.136 & 1.025 \\
\hline Tap water & 0.540 & 1.136 & 1.023 & 0.900 & 0.490 & 1.023 & 0.923 & 0.812 \\
\hline Means $(A)$ & 0.646 & 1.266 & 1.143 & & 0.585 & 1.141 & 1.030 & \\
\hline \multirow[t]{3}{*}{ L.S.D. at $5 \%$} & A: 0.064 & B: 0 & & AB: 0.092 & $A: 0.058$ & B: 0 & & $A B: 0.084$ \\
\hline & \multicolumn{8}{|c|}{ Season 2} \\
\hline & \multicolumn{4}{|c|}{ First cut } & \multicolumn{4}{|c|}{ Second cut } \\
\hline Magnetized water & 0.830 & 1.536 & 1.390 & 1.252 & 0.743 & 1.386 & 1.253 & 1.127 \\
\hline Tap water & 0.593 & 1253 & 1.123 & 0,990 & 0.530 & 1.126 & 1013 & 0.890 \\
\hline Means (A) & 0.711 & 1.395 & 1.256 & & 0.636 & 1.256 & 1.133 & \\
\hline \multirow[t]{4}{*}{ L.S.D. at $5 \%$} & A: 0.071 & B: 0 . & & AB: 0.101 & A: 0.064 & B: 0 & & $A B: 0.092$ \\
\hline & \multicolumn{8}{|c|}{ Essential oil yield per plant $(\mathrm{ml})$} \\
\hline & \multicolumn{8}{|c|}{ Season 1} \\
\hline & \multicolumn{4}{|c|}{ First cut } & \multicolumn{4}{|c|}{ Second cut } \\
\hline Magnetized water & 0.146 & 0.393 & 0.313 & 0.284 & 0.156 & 0.423 & 0.336 & 0.305 \\
\hline Tap water & 0.086 & 0.266 & 0.206 & 0.186 & 0.093 & 0.286 & 0.226 & 0.202 \\
\hline Means (A) & 0.116 & 0.330 & 0.260 & & 0.125 & 0.355 & 0.281 & \\
\hline \multirow[t]{3}{*}{ L.S.D.at $5 \%$} & A: 0.034 & B: 0 . & & $A B: 0.039$ & A: 0.036 & & .021 & $A B: 0.041$ \\
\hline & \multicolumn{8}{|c|}{ Season 2} \\
\hline & \multicolumn{4}{|c|}{ First cut } & \multicolumn{4}{|c|}{ Second cut } \\
\hline Magnetized water & 0.193 & 0.520 & 0.410 & 0.374 & 0.123 & 0.330 & 0.266 & 0.240 \\
\hline Tap water & 0.116 & 0.353 & 0.276 & 0.248 & 0.073 & 0.226 & 0.176 & 0.158 \\
\hline Means (A) & 0.155 & 0.436 & 0.343 & & 0.098 & 0.278 & 0.221 & \\
\hline L.S.D. at $5 \%$ & A: 0.041 & B: 0 & & $\mathrm{AB}: 0.047$ & A: 0.033 & B: 0 & & $A B: 0.036$ \\
\hline
\end{tabular}

Table (8). Effect of irrigation water type, N-fertilizer rates and their interaction on essential oil component of Majorana hortensis L plants in the second cut of 2014/2015 season. 
Doi: 10.21608/asajs.2020.67987

\begin{tabular}{|c|c|c|c|c|c|c|c|}
\hline Treatments & RT & $\begin{array}{c}\text { Magnetized } \\
\text { water } \\
+ \\
14 \text { g/pot }\end{array}$ & $\begin{array}{c}\text { Magnetized } \\
\text { water } \\
+ \\
7 \text { g/pot }\end{array}$ & $\begin{array}{l}\text { Magnetized } \\
\text { water }\end{array}$ & $\begin{array}{c}\text { Tap } \\
\text { water }\end{array}$ & $\begin{array}{c}\text { Tap water } \\
+ \\
7 \text { g/pot }\end{array}$ & $\begin{array}{c}\text { Tap water } \\
+ \\
14 \text { g/pot }\end{array}$ \\
\hline 1-Phellandrene & 4.57 & 0.35 & 0.39 & 0.35 & 0.42 & 0.33 & 0.35 \\
\hline$\alpha$-Pinene & 4.77 & 0.56 & 0.61 & 0.62 & 0.60 & 0.61 & 0.58 \\
\hline Sabinene & 5.80 & 4.86 & 5.63 & 5.30 & 5.91 & 5.38 & 5.10 \\
\hline$\beta$-Pinene & 5.96 & 0.33 & 0.35 & 0.34 & 0.35 & 0.36 & 0.33 \\
\hline$\alpha$-Mbrcene & 6.23 & 1.08 & 0.94 & 0.70 & 0.89 & 0.85 & 0.79 \\
\hline$\alpha$-Terpinene & 7.12 & 5.91 & 6.51 & 5.12 & 4.31 & 3.46 & 4.27 \\
\hline O-Cymene & 7.44 & 3.75 & 3.07 & 3.29 & 4.21 & 4.55 & 5.00 \\
\hline D-Limonene & 7.53 & 1.08 & 1.08 & 1.01 & 1.12 & 1.11 & 1.07 \\
\hline$\alpha$-Phellandrene & 7.62 & 1.13 & 1.23 & 1.17 & 1.08 & 1.09 & 1.04 \\
\hline C--Terpinene & 8.54 & 12.45 & 12.34 & 9.65 & 8.81 & 7.57 & 8.87 \\
\hline Terpineol & 9.06 & 0.13 & 2.55 & 5.43 & 6.27 & 6.75 & 3.68 \\
\hline$\alpha$-Terpinolene & 9.50 & 2.40 & 2.48 & 1.93 & 1.91 & 1.66 & 1.87 \\
\hline L-Linalool & 10.15 & 3.48 & 2.35 & 1.59 & 2.64 & 1.99 & 2.00 \\
\hline 4-Thujanol & 10.24 & 0.29 & 6.48 & 15.85 & 15.39 & 20.17 & 8.98 \\
\hline Terpenene-1-ol & 11.16 & 1.15 & 1.53 & 1.78 & 1.67 & 1.73 & 1.63 \\
\hline 2-Cyclohexen-1-ol & 11.91 & 0.92 & 0.99 & 0.85 & 0.80 & 0.78 & 0.97 \\
\hline L-Menthone & 12.87 & 0.09 & 0.05 & 0.19 & 0.06 & 0.14 & 0.41 \\
\hline 1-Borneol & 13.16 & 0.12 & 0.13 & 0.10 & 0.05 & 0.07 & 0.10 \\
\hline Terpineol-4-ol & 13.49 & 43.38 & 34.15 & 32.54 & 26.41 & 27.50 & 32.46 \\
\hline$\alpha$-Terpineol & 14.16 & 3.53 & 2.99 & 2.85 & 2.97 & 3.21 & 3.43 \\
\hline 2-Cyclohexen-1-ol & 14.72 & 0.50 & 0.36 & 0.17 & 0.24 & 0.23 & 0.44 \\
\hline Linably acetate & 16.20 & 6.35 & 6.70 & 2.97 & 5.66 & 3.36 & 5.19 \\
\hline Bornylacetate & 17.74 & 0.18 & 0.36 & 0.12 & 0.29 & 0.27 & 0.36 \\
\hline 4-Terpinenyl acetate & 18.24 & 0.26 & 0.37 & 0.24 & 0.38 & 0.26 & 0.42 \\
\hline Carxophyllene & 23.18 & 2.97 & 3.01 & 2.81 & 3.84 & 3.22 & 4.19 \\
\hline$\alpha$-Humulene. & 24.70 & 0.11 & 0.11 & 0.12 & 0.14 & 0.12 & 0.10 \\
\hline Bicyclogermacxene & 26.33 & 1.70 & 2.45 & 1.73 & 2.36 & 1.90 & 1.75 \\
\hline Spathulenol & 29.71 & 0.11 & 0.10 & 0.06 & 0.17 & 0.36 & 0.34 \\
\hline Carzophyllene oxide & 29.84 & 0.19 & 0.19 & 0.27 & 0.28 & 0.27 & 0.48 \\
\hline C-endesmol & 31.40 & 0.14 & 0.10 & 0.34 & 0.17 & 0.22 & 1.14 \\
\hline Isaspathulenol & 31.84 & 0.13 & 0.07 & 0.10 & 0.21 & 0.10 & 0.29 \\
\hline
\end{tabular}

Thirty compounds accounting for more than $99 \%$ of the total volatiles in most marjoram samples were detected and identified. There are differences in oil composition as affected by type of irrigation water and different rates of $\mathrm{N}$-fertilizer. The predominant compounds presented under all treatments were recorded in table (8). Data revealed that application of magnetized water with $14 \mathrm{~g} /$ pot of $\mathrm{N}$-fertilizer recorded the highest percentage of terpinen-4-ol (the major compound in marjoram oil), $\alpha$-terpinene, $\alpha$-phellandrene, Ç-terpinene, $\alpha$ terpinolene, L-linalool, 2-cyclohexen-1-ol, L-menthone, 1- 
borneol, $\alpha$-terpineol and 2-cyclohexen-1-ol and linalool acetate, accompanied by a decrease in the other components, compared to the tap water (unmagnetized water) and other treatments. Some of these components are used for scenting cosmetics and others are used for flavoring pharmaceuticals; such as Dlimonene and linalool (Refaat, 1988).

\section{Total Carbohydrate Percentage \\ 4.1. Effect of irrigation water type}

The data reported in table (9) indicate that, irrigation with magnetized water treatment gave an increase in total carbohydrate percentage compared to irrigation with tap water, and this increase is statistically significant. These results hold the same direction in the two seasons.

These results may be due to the easy absorption of magnetized water by roots that has led to an increase in the absorption of nutrients and thus increases the photosynthesis process, leading to an increase in the material tending starchy and sugary and thus an increase in carbohydrate percentage (Pietruszewski, 1999).

\subsection{Effect of $\mathbf{N}$-fertilizer rates}

From data presented in table (9), it is obvious that, Nfertilizer treatments increased total carbohydrate percentage compared to control in the two seasons. Moreover, the best treatment in increasing total carbohydrate percentage was 14 $\mathrm{g} /$ pot and the results were statistically significant.

These results may be due to the effective role of $\mathrm{N}$ fertilizer rates with the suitable role for increasing the plant growth and consequently increasing the absorption rate of elements and increasing the photosynthesis, which was reflected in enhancing the percentage of carbohydrate. These results are in agreement with those reported by Kumawat and Gaur (2004) on psyllium and El-Shakry (2005) on sweet fennel plants. 


\subsection{Effect of interaction}

The results presented in table (9) indicate that, increasing $\mathrm{N}$-fertilizer rates under type of irrigation water increased total carbohydrate percentage of majoram plant.

The interaction between using magnetized water plus 14 $\mathrm{g} /$ pot, magnetized water plus $7 \mathrm{~g} /$ pot and tap water plus $14 \mathrm{~g} / \mathrm{pot}$ of $\mathrm{N}$-fertilizer treatments gave increase in total carbohydrate percentage, and this increase was significant, compared to other treatments and control (tap water). However, the treatments of tap water plus $14 \mathrm{~g} /$ pot, tap water plus $7 \mathrm{~g} /$ pot and magnetized water gave an increase in total carbohydrate percentage and this increase was insignificant compared to each of the other treatments and control treatment (tap water). The highest values in this respect were obtained by using $14 \mathrm{~g} / \mathrm{pot}$ of $\mathrm{N}$-fertilizer combined with magnetized water comparing with the other interactions. This treatment gave a highly significant increase comparing with other interactions. These results hold the same direction in the two seasons.

These results may be attributed to the speed of roots absorption of magnetized water to an increase in the absorption of nutrients, which led to revitalize the role of nitrogen and an increase in photosynthesis, and therefore, tend to increase carbohydrates (Jones, 1986). These results are in agreement with those obtained by Omer et al. (2008) on Ocimum americanum. 


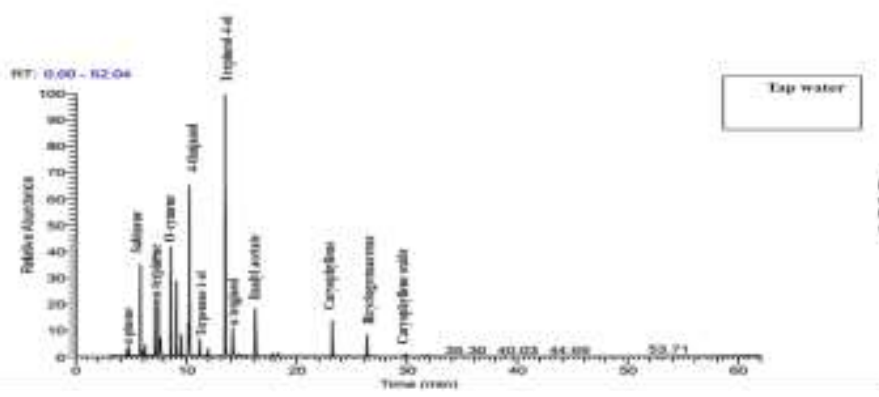

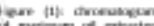

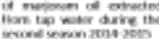
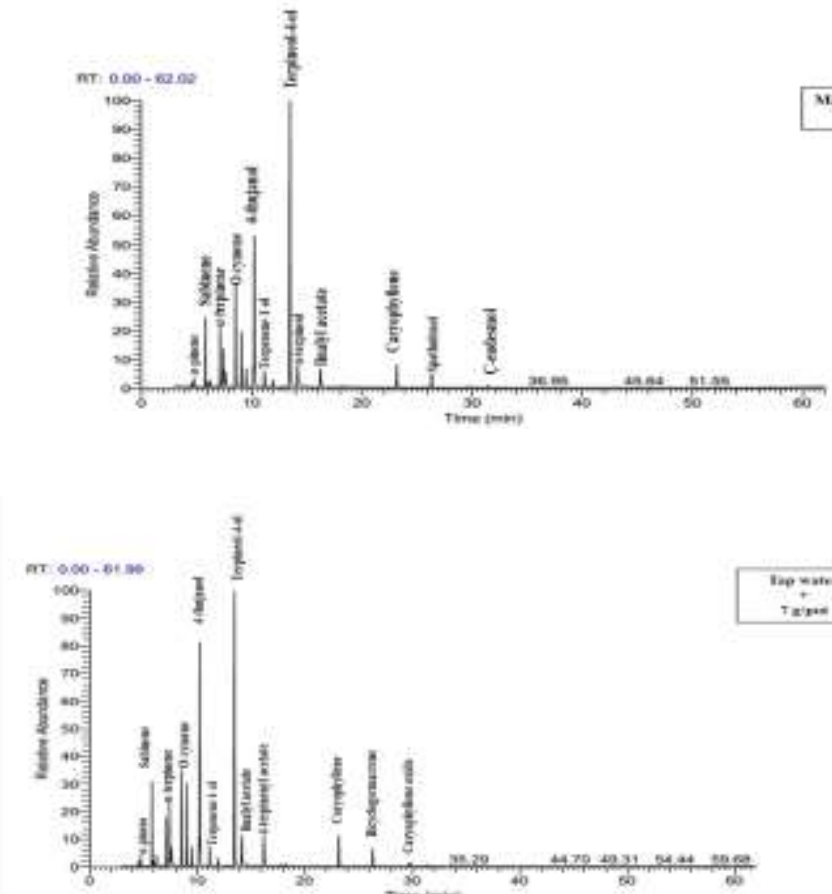

Nagnestiest

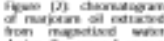

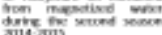
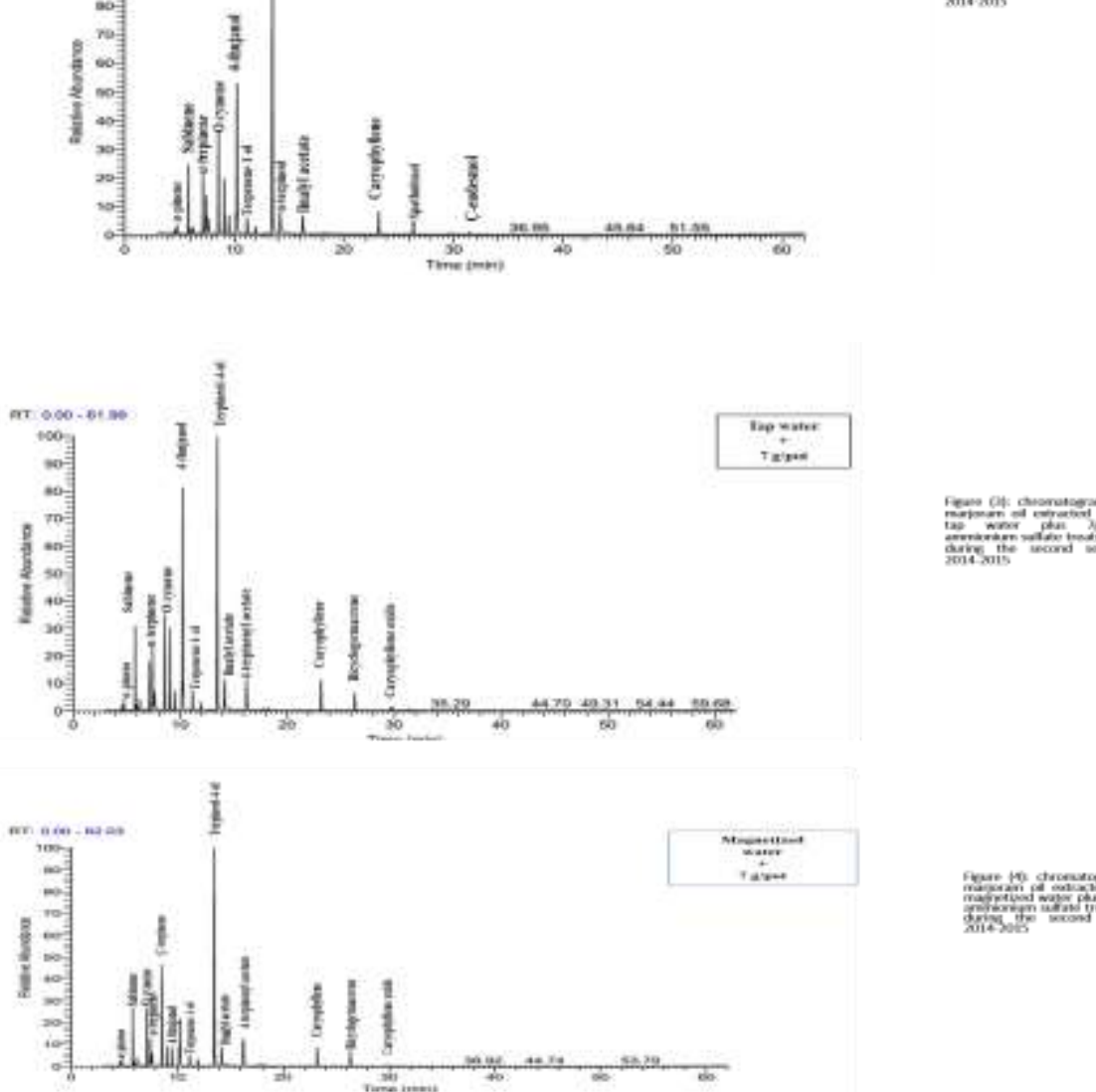

Nentexts

tas.

Q

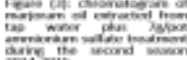

antive

ton 

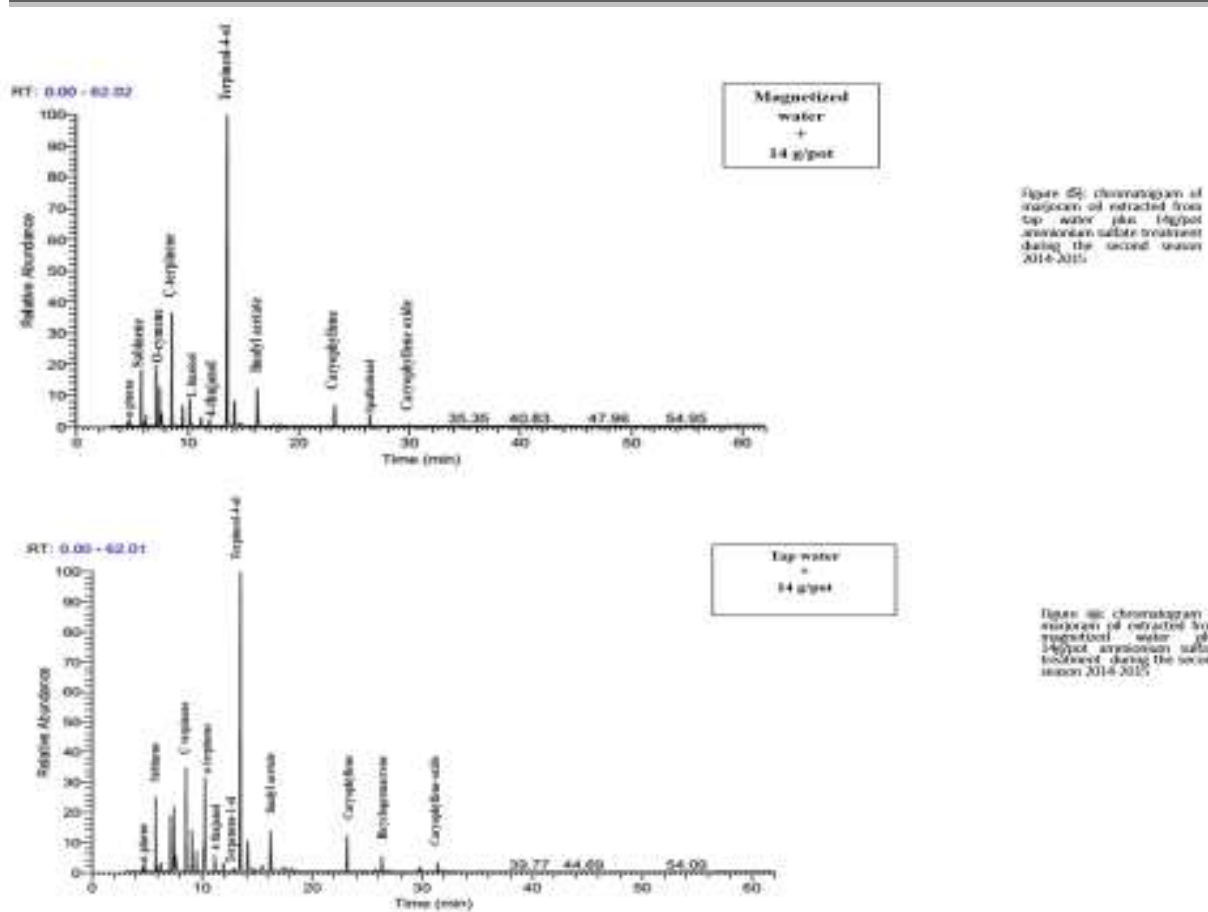

\section{Total Nitrogen, Phosphorus and Potassium Percentages \\ 5.1. Effect of irrigation water type}

Table (9) showed that, plants irrigated with magnetized water, total nitrogen, phosphorus and potassium percentages increased in the two cuts in both seasons. At the same time, these parameters were significantly increased as a result of using magnetized water treatment compared to the other treatments. The superior treatments in this concern were that irrigation of plants with magnetized water, which showed higher increase in this respect compared to the other treatments in the two seasons.

The increase may be due to the role of magnetized water in excess soluble salts in the soil and increase the efficiency of absorption and movement of nutrients from the soil to the roots and then speed to shoot (Kronenberg, 2005). These results are in line with those stated by Atak et al. (1997) and Özalpan et al. (1999) on soybean. 


\subsection{Effect of $\mathrm{N}$-fertilizer rates}

From the data presented in table (9), it is obvious that, Nfertilizer rates at all treatments increased total nitrogen, phosphorus and potassium percentages compared to control in the two seasons. Moreover, the best treatment for increasing total nitrogen, phosphorus and potassium percentages was tap water with $14 \mathrm{~g}$ plus/pot of $\mathrm{N}$-fertilizer.

These results may be due to the effective role of $\mathrm{N}$ fertilizer with the suitable role for increasing the plant growth and consequently increasing the absorption rate of $\mathrm{N}, \mathrm{P}$ and $\mathrm{K}$, which was reflected in enhancing the percentages of these elements. Such results are in harmony with those reported by Dasha et al. (2006) on Mentha arvensis and Phuong et al. (2008) on Ocimum basilicum.

\subsection{Effect of interaction}

As shown in table (9), it is clear that the plants irrigated with magnetized water under $\mathrm{N}$-fertilizer rates; nitrogen, phosphorus and potassium percentages increased and this increase was significant compared to other treatments and control (tap water). Moreover, the interaction between types of irrigation water under $\mathrm{N}$-fertilizer rates caused significant increase in nitrogen, phosphorus and potassium percentages of marjoram plant. Also, increasing the $\mathrm{N}$-fertilizer rates under type of water irrigation caused a significant increase in total nitrogen, phosphorus and potassium percentages. However, the superior treatments in this regard were plants irrigated with magnetized water and using $14 \mathrm{~g} / \mathrm{pot} \mathrm{N}$-fertilizer comparing to other treatments.

It may be caused as a result of that magnetized water and nitrogen led to increasing the efficiency of nutrient uptake and increased movement of nutrients from the soil to the roots and thus increases the absorption rate of $\mathrm{N}, \mathrm{P}$ and $\mathrm{K}$, which was 
reflected in strengthening the ratios of these elements within the plant cells (Namba et al., 1995). These results agree with those obtained by Oldacay and Erdem (2002) on Helianthus annuus, and Dasha et al. (2006) on Mentha arvensis.

Table (9). Effect of irrigation water type, $\mathbf{N}$-fertilizer rates and their interaction on total carbohydrate, nitrogen, phosphorus and potassium percentages of Majorana hortensis plant in 2013/2014 and 2014/2015 seasons.

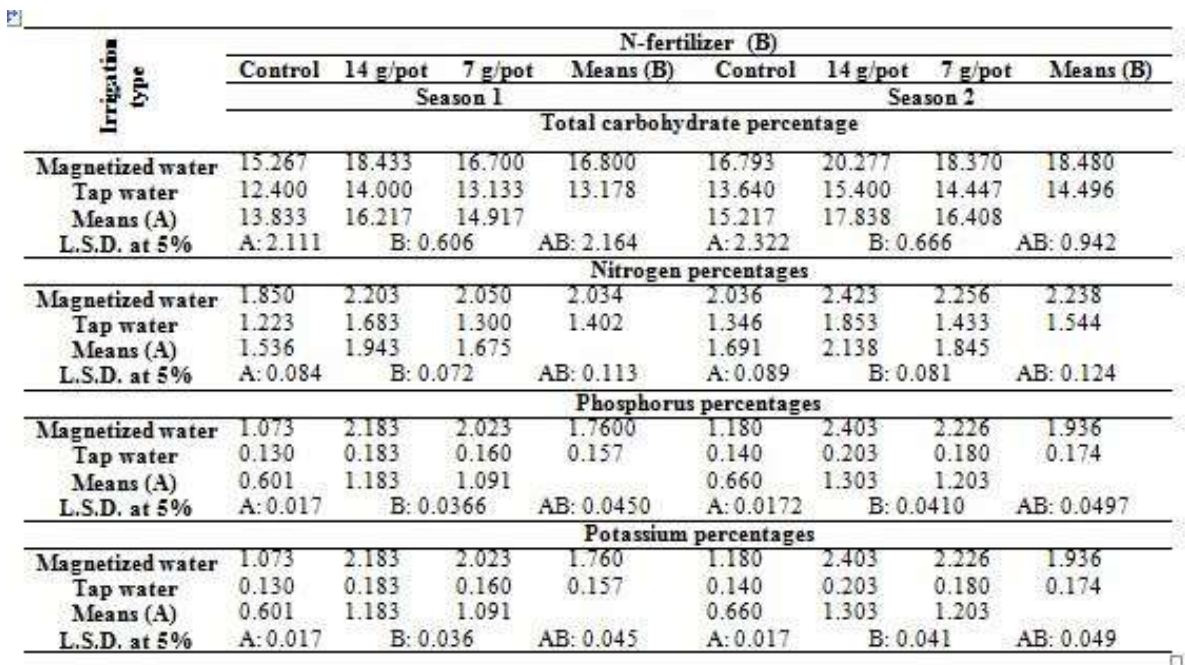




\section{r.r.r. المجلد الثالث-العدد (0 ) يناير}

\section{المجلة العربية للعلور الزراعية}

\section{REFERENCES}

Alsafar, M.S. and Y.M. Al-Hassan (2009). Effect of nitrogen and phosphorus fertilizers on growth and oil yield of indigenous mint (Mentha longifolia L.). Biotechnology Journal, 8 (3): 380-384.

Al-Said, Ahl H.A.H. (2005). Physiological studies on growth, yield and volatile oil of dill (Anethum graveolens). Ph.D. Thesis, Fac. Agro., Cairo Univ., Cairo, Egypt.

Analytical Software (1985). Data analysis software for researchers 1985.

Atak, Ç., V. Danilov, B. Yurttafl, S. Yalçn, D. Mutlu and A. Rzakoulieva (2000). Effect of magnetic field on Paulownia seeds. Com. JINR Dubna, 1-14.

Atak, C., V. Danilov, B. Yurttas, S. Yalçn, D. Mutlu and A. Rzakoulieva (1997). Effects of magnetic field on soybean (Glycine max L. Merrill) seeds. Com. JINR. Dubna, 1-13. Baranauskienne, R., P.R. Venskutonis, P. Viskelis and E. Dambrausiene (2003). Influence of nitrogen fertilizer on the yield and composition of thyme (Thymus vulgaris), J. Agric. Food Chem., 51: 7751-7758.

Belyavskaya, N. A. (2001). Ultrastructure and calcium balance in meristem cells of pea roots exposed to extremely low magnetic field. Adv. Space Res., 28 (4): 645-650.

British Pharmacopoeia (1936). In "Determination of Volatile Oil in Drugs". Published by the Pharmaceutical Press, London.

Brown, J. D. and D. Lilleland (1946). Rapid determination of potassium and sodium in plant material and soil extracts by flam photometry. Proc. Amer. Soc., Hort. Sci., 48: 341 346.

Bunzen, J., N. Guichard, P. Labbr, J. Prevot and J. Trenchant (1969). Practical Manual of Gas Chromatography. J. 
Ttenchant, Ed. El-Sevier Pubication Compony, Amesterdam, Netherland.

Carbonell, M.V., E. Martinez and J.M. Amaya (2000). Stimulation of germination in rice (Oryza sativa L.) by a static magnetic field. Electro-Magnetobiol., 19 (1): 121128.

Çelik, Ö., Ç.A. Atak and A. Rzakulieva (2008). Stimulation of rapid regeneration by a magnetic field in paulownia node cultures. J. Central Europ. Agric., 9 (2): 297-304.

Colic, M., A. Chien and D. Morse (1998). Synergistic application of chemical and electro magnetized water treatment in corrosion and scale prevention. Croatica Chemica Acta, 71 (4): 905-916.

Dasha, R., R. Muni, and S. Ranjeet (2006). Optimization of water and nitrogen application to menthol mint (Mentha arvensis L.) through sugarcane trash mulch in a sandy loam soil of semi-arid subtropical climate. Bioresource Technology, 97 (7): 886-893.

El-Ghorab, A.H., A.F. Mansour and K.F. El-Massry (2004). Effect of extraction methods on the chemical composition and antioxidant activity of Egyptian marjoram (Majorana hortensis Moench). Flav. Fragr. J., 19: 54-61.

El-Shakry, M.F.Z.S. (2005). Effect of bio-fertilizers, nitrogen sources and levels on vegetative growth characters, yield and quantity and oil content of sweet fennel plants. Ph.D. thesis, Fac. Agric., Cairo Univ., Egypt.

Edris, A.E., S. Ahmad and H.M. Fadel (2003). Effect of organic agriculture practices on the volatile aroma components of some essential oil plants growing in Egypt II: sweet marjoram (Origanum marjorana L.) essential oil. Flavour Fragr. J., 4: 345-51. 
Farkas, J. (1981). Perioral dermatitis from marjoram, bay leaf and cinnamon. Contact Dermatitis, 7 (2): 121.

Herbert, D., P.J. Phipps, and R.E. Strange (1971) Chemical Analysis of Microbial Cells. Methods in Microbiology, 5, 209-344.

http://dx.doi.org/10.1016/S0580-9517(08)70641-X

Hilal, M.H., S.M. Shata, A.A. Abdel-Dayem and M.M. Hillal (2002). Application of magnetic technologies in desert agriculture. III- Effect of magnetized water on yield and uptake of certain elements by citrus in relation to nutrients mobilization in soil. Egypt J. Soil Sci., 42 (1): 43-55.

Hoftman, E. (1967). Chromotography, Reinhild. Corp., $2^{\text {nd }}$ Ed. p. 208-515.

Hozayn, M. and Amira M.S. Abdul Qados (2010). Irrigation with magnetized water enhances growth, chemical constituent and yield of chickpea (Cicer arietinum L.). Agriculture and Biology Journal of North America, Online: 2151-7525, Science $\mathrm{Hu} \beta$.

Jones, D.B., G.P. Bolwell and G.J.J. Gilliat (1986). Amplification, by pulsed electromagnetic fields, of plant growth regulator induced phenylalanine ammonia-lyase during differentiation in suspension cultured plant cells. Bio Electricity, 5 (1): 1-12.

Koch, F.C. and T.L. Mc-Meekin (1924). A new direct nesslarization micro-Kjeldahl method and modification of the Nesslar folia reagent for ammonia. J. Amer. Chem. Soc., 46: 2066.

Kronenberg, K.J. (2005). Magneto hydrodynamics: The effect of magnets on fluids GMX international,USA.

Kumawat, S.K. and B.L. Gaur (2004). Effect of sowing methods, nitrogen and weed management on quality of Blond 
psyllium (Plantago ovata Forsk) Annals of Agricultural Research, 25 (3): 346-349.

Leeja, L. and J.E. Thoppil (2007). Antimicrobial activity of methanol extract of Origanum majorana L. (Sweet marjoram). J. Environ. Biol., 28 (1): 145-146.

Maheshwari, B.L. and H.S. Grewal (2009). Magnetic treatment of irrigation water: Its effects on vegetable crop yield and water productivity. Agric. Water Manage., 96: 1229-1236.

Maheshwari, S.K.; Sharma, R.K. and Gangrade, S.K. 2000. Performance of isabgol or blond psyllium (Plantago ovata Forsk.) under different levels of nitrogen, phosphorus and biofertilizers in shallow black soil. Indian J. Agron. 45 (2) : 443-446.

Marinkovic, B., Z. Ilin, J. Marinkovic, M. Culibrk and G. Jacimovic (2002). In "Potato Yield in Function Variable Electromagnetic Field". Biophysics in Agriculture Production. University of Novi Sad, Tomograf.

Martinez, E., M.V. Carbonell and J.M. Amaya (2000). A static magnetic field of $125 \mathrm{mT}$ stimulates the initial growth stages barley (Hordeum vulgare L.). Electro and Magnetobiol., 19(3): 271-277.

Min, S.Y., A.R.M. Tawaha and K.D. Lee (2005). Effects of ammonium concentration on the yield, mineral content and active terpene components of Chrysanthemum coronarium L. in a hydroponic system. Res. J. Agric. Biol. Sci., 1 (2): 170-175.

Namba, K., A. Sasao and S. Shibusawa (1995). Effect of magnetic field on germination and plant growth. Acta Horticulturae, 399: 143-147.

Nasher, S. H. (2008). The Effect of magnetic water on growth of chick--pea seeds. Eng. Tech., 26 (9): 4 pages.

Oldacay, S. and G. Erdem (2002). Evaluation of chlorophyll contents and peroxides activities in I (Helianthus annuus 
L.) genotypes exposed to radiation and magnetic field. Pak. J. of Appl. Sci., 2 (10): 934-937.

Omer, E.A., A.A. Elsayed, A. El-Lathy, A.M.E. Khattab and A.S. Sabra (2008). Effect of the nitrogen fertilizer forms and time of their application on the yield of herb and essential oil of Ocimum americanum L. Herba Polonica, 54 (1): 34-46.

Özalpan, A., C. Atak, B. Yurttas, S. Alikamanoglu, Y. Canbolat, H. Borucu, V. Danilov and A. Rzakoulieva (1999). Effect of magnetic field on soybean yield (Glycine $\max \mathrm{L}$. Merrill). Turkish Association of Biophysics, XI National Biophysics Congress, Abstract Book, 60 pp.

Pietruszewski, S.T. (1999). Effect of alternating magnetic field on germination, growth and yield of plant seeds. Int. Agrophysics, 5 (11): 209-215.

Phuong, M., Nguyen and Emily, D. Niemeyer (2008). Effects of nitrogen fertilizer on the phenolic composition and antioxidant properties of basil (Ocimum basilicum L.) J. Agric. Food Chem., 56 (18): 8685-8691.

Rao, A.P. (2002). Scale master ECO friendly water treatment. Scale-master Adlam Pvt. Ltd. Available online: www.adlams.com/attachment-Scal.

Refaat, Azza M. (1988). Effect of fertilizer levels, methods of drying and periods of storage on the sweet marjoram herb yield and its active ingredients. Ph.D. Thesis, Fac. Agric., Ain Shams Univ., Cairo.

Sharma, P. K., G.L. Yadav, K. Sudesj and M.M. Singh (2003). Effect of methods of sowing and nitrogen level on the yield of psyllium (Plantago ovata). Journal of Medicinal and Aromatic Plant Sciences, 25 (3): 672-674.

Singh, M. and S. Ramesh (2000). Effect of irrigation and nitrogen on herbage, oil yield and water-use efficiency in 
rosemary grown under semi-arid tropical conditions. J. Med. Aromatic Plant Sci., 22 (IB): 659-662.

Snedecor, G.W. and G.W Cochran (1980). In "Statistical Methods" ( $7^{\text {th }}$ Ed.) Iowa State Univ., Press, Amer., Iowa, USA.

Tahraoui, A., J. El Hilaly and Z.H. Israili, B. Lyoussi ( 2007). Ethnopharmacological survey of plants used in the traditional treatment of hypertension and diabetes in southeastern Morocco (Errachidia province). J Ethnopharmacol., 110 (1): 105-117.

Takac, A., G. Gvozdenovic and B. Marinkovic (2002). Effect of resonant impulse electromagnetic stimulation on yield of tomato and pepper. Biophysics in Agriculture Production, University of Novi Sad, Temporal.

Triantaphyllou, K., G. Blekas and D. Boskou (2001). Antioxidative properties of water extracts obtained from herbs of the species Lamiaceae. Int. J. Food Sci. Nutr., 52 (4): 313-317.

Troug, E. and A. Mayer (1939). Improvement in the direness colorimetric method for phosphorus and arsenic. Ind. Eng. Chem. Anal., 1: 136-139.

Usha, Kiran and D.D. Patra (2003). Medicinal and aromatic plant materials as nitrification inhibitors for augmenting yield and nitrogen uptake of Japanese mint (Mentha arvensis L. var. piperascens). Bio-resource Technology, 6 (3): 267-276. 